\title{
Granularity and textural analysis as a proxy for extreme wave events in southeast coast of India
}

\author{
C S Vijaya Lakshmi, ${ }^{1, *}$ P Srinivasan ${ }^{2}$, S G N Murthy ${ }^{2}$, \\ Deshraj TRIVEDi ${ }^{1}$ and Rajesh R NAIR ${ }^{1}$ \\ ${ }^{1}$ Department of Geology $\&$ Geophysics, Indian Institute of Technology, Kharagpur 721 302, India. \\ ${ }^{2}$ Structural Engineering Research Centre, Chennai 600 113, India. \\ *e-mail:viji.iitkgp@gmail.com
}

\begin{abstract}
Extreme wave events of 1000 and 1500 years (radiocarbon ages) have been recently reported in Mahabalipuram region, southeast coast of India. Subsequently, we carried out extensive sedimentological analysis in regions covering a total lateral coverage of $12 \mathrm{~km}$ with a new archeological site as the central portion of the study area. Twelve trenches in shore normal profiles exhibit landward thinning sequences as well as upward fining sequences confirming with the global signatures of extreme wave events. The sediment size ranges from fine-to-medium and moderately well sorted-to-well sorted, and exhibit positive skewness with platykurtic-to-leptokurtic nature. We now propose the abrupt winnowing or back and forth motion including unidirectional transport of these deposited sediments, which results in positive skewness. Textural analyses derived from scanning electron microscope studies (SEM) demonstrate the alteration produced, in the ilmenite mineral with vivid presence of pits and crescents with deformation observed on the surface due to extreme wave activities. This is further confirmed with the predominance of high-density mineral such as magnetite (5.2) and other heavy minerals in these deposits inferred the high-intensity of the reworking process of the beach shelf sediments.
\end{abstract}

\section{Introduction}

Identification of tsunami deposits and other highenergy events is still debatable and several studies have pointed out many hypotheses regarding the diagnostic characteristics of tsunami deposits (Kortekaas and Dawson 2007; Morton et al 2007; Tappin 2007). Several studies contributed to the confirmation of sedimentological signatures in regions like Kenya, southwest coast of India, west Banda Aceh, Peru, Papua New Guinea, southern Kuril trench by Bahlburg and Weiss (2007), Babu et al (2007), Morton et al (2007), Nanayama et al (2007), Paris et al (2007). These studies have revealed that low frequent high magnitude events leave clear geological markers in the coastal landscape (Costa 2006; Bahlburg and Weiss 2007). However, it is understood that these features vary with respect to coastal geomorphology, frequency of high-energy events, erosion, transportation as well as depositional environment (Bahlburg and Weiss 2007; Paris et al 2007). Critical studies by Dawson (1999), Kortekaas and Dawson (2007), Tappin (2007), Nanayama et al (2007) in Martinhal, southwest Portugal, southern Kuril trench, Papua New Guinea, Peru demonstrate that graded bedding, fining upward sequences and landward thinning sequences are ideal characteristics for tsunamigenic deposits. Nanayama et al (2000), Jaffe et al (2006) and Morton et al (2007), reported that the storm surges could be identified by poor sorting, presence of prominent sediment structures, e.g., hummocky cross stratification, absence of shell laminae based on the studies in the Gulf of Mexico and 2003 Hurricane Isabel western Atlantic Ocean. Goff et al (2004)

Keywords. Extreme wave events; grain size analysis; tsunami deposits; texture; surges; sorting. 


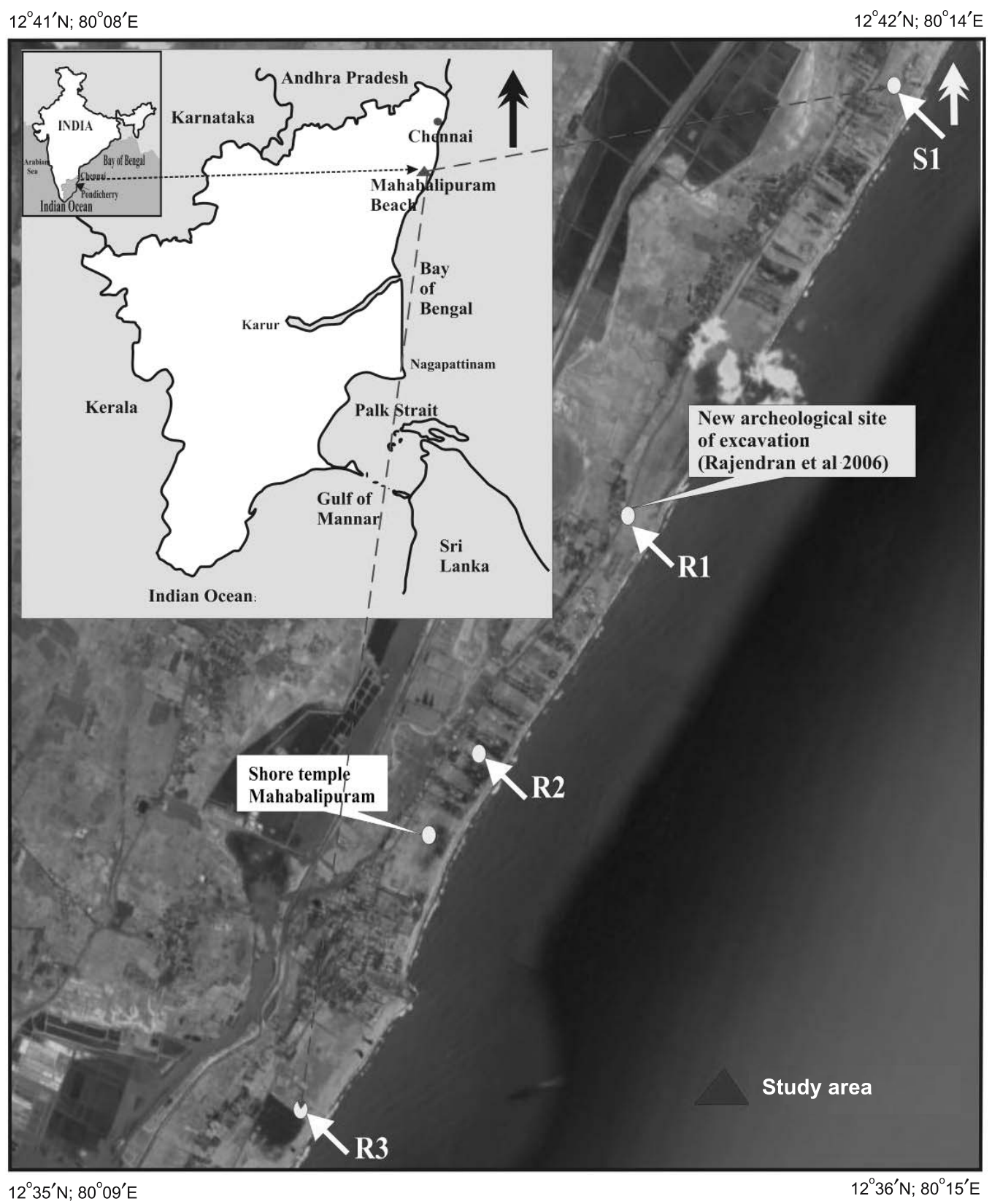

Figure 1. Study region showing four profiles (S1, R1, R2, and R3, lateral distance of around $12 \mathrm{~km}$ ) from which samples has been collected for analysis; inset is the location map of Tamil Nadu coastal region and the triangle indicates the study region (Source: http://www.maps-india.com/tamilnadu/tn-map/mahabalipuram-beach.gif, and Google earth 2009).

reported storm deposits as not being locally extensive and their mean size being coarser than that of tsunami observed in southeastern North Island, New Zealand. Paris et al (2007) in west Banda Aceh region, using GPS studies as well as grain size analysis confirm that the deposits are well buried and preserved which provide knowledge of the past events. Recently, Monecke et al (2008) obtained a 1000-year sedimentary record of 2004 tsunami deposits as a massive sand bed $(25 \mathrm{~cm})$ overlying organic-rich marsh deposits and these features were preserved from 1-2 $\mathrm{m}$ swales in northern Sumatra where the waves reached a maximum height of $35 \mathrm{~m}$. The grain size distribution of sediments was measured along three to four transects which revealed a clear landward fining trend with poorer sorting. Jankaew et al (2008) obtained significant diagnostic features at a grassy beach ridge plain, $125 \mathrm{~km}$ north of Phuket in Thailand. They obtained these signatures in a region spanning $2 \mathrm{~km}$ across the plain, coated the ridges and intervening swales with sand sheets of 5-20 cm thickness. They further demonstrated that two-marked sheet swale preserves the paleoevents younger than 2800 years and predicted a 550-700 year predecessor to the 2004 tsunami. The swales lack sedimentary 
structures because of bioturbation that distorts their contacts with the soils, and the sandsheets exhibit typical fining upward sequences.

Rajendran et al (2006) examined the two trenches in Mahabalipuram, $55 \mathrm{~km}$ south of Chennai, east coast of India, which was severely affected by the 2004 tsunami. They obtained two extreme wave events occurring at 1000 and 1500 years, respectively. They found two anomalous layers of sand; the younger one marked as S1 $(10-14 \mathrm{~cm})$ and the older one marked as S2 $(10 \mathrm{~cm})$ at ASI site Saluvankuppam, Mahabalipuram. We carried out an extensive survey in summer 2008-2009 in three trenches (R1a, R1b and R1c) along the N-S profile from the ASI site (Rajendran et al 2006), $50 \mathrm{~m}$ normal to the shore and in other nine trenches in three more profiles (S1a, S1b, S1c, R2a, R2b, R2c, R3a, R3b and R3c).

Figure 1 shows the broad location of the study area. Figure 2 demonstrates the elevation of the four profiles $\mathrm{S} 1, \mathrm{R} 1, \mathrm{R} 2$, and $\mathrm{R} 3$ with respect to mean sea level with twelve trenches (S1a, S1b, S1c, R1a, R1b, R1c, R2a, R2b, R2c, R3a, R3b and R3c). The distance of the trenches from the shore are S1a $-40 \mathrm{~m}, \mathrm{~S} 1 \mathrm{~b}-60 \mathrm{~m}, \mathrm{~S} 1 \mathrm{c}-75 \mathrm{~m}$, $\mathrm{R} 1 \mathrm{a}-40 \mathrm{~m}, \mathrm{R} 1 \mathrm{~b}-50 \mathrm{~m}, \mathrm{R} 1 \mathrm{c}-65 \mathrm{~m}, \mathrm{R} 2 \mathrm{a}-35 \mathrm{~m}$, $\mathrm{R} 2 \mathrm{~b}-65 \mathrm{~m}, \mathrm{R} 2 \mathrm{c}-140 \mathrm{~m}, \mathrm{R} 3 \mathrm{a}-15 \mathrm{~m}, \mathrm{R} 3 \mathrm{~b}-26 \mathrm{~m}$ and $\mathrm{R} 3 \mathrm{c}-37 \mathrm{~m}$, respectively. The thickness of the deposits analyzed for granularity as well as textural studies within the trenches were $\mathrm{S} 1 \mathrm{a}-2 \mathrm{~m}$, $\mathrm{S} 1 \mathrm{~b}-2 \mathrm{~m}, \mathrm{~S} 1 \mathrm{c}-1.5 \mathrm{~m}, \mathrm{R} 1 \mathrm{a}-1 \mathrm{~m}, \mathrm{R} 1 \mathrm{~b}-0.5 \mathrm{~m}$, R1c $-0.75 \mathrm{~m}, \mathrm{R} 2 \mathrm{a}-1.5 \mathrm{~m}, \mathrm{R} 2 \mathrm{~b}-0.75 \mathrm{~m}, \mathrm{R} 2 \mathrm{c}-$ $0.75 \mathrm{~m}, \mathrm{R} 3 \mathrm{a}-1 \mathrm{~m}, \mathrm{R} 3 \mathrm{~b}-1.25 \mathrm{~m}$ and $\mathrm{R} 3 \mathrm{c}-2 \mathrm{~m}$. The fining upward sequences or grading sequences is well represented in the vertical section of graphic log with coarse sand at the base lacking mudclasts overlained by black sands rich in heavy minerals and the analyzed samples (quartz rich fine sand) and loose sands with grassroots at the top. The deposits occur as single homogenous deposits and the lateral extensions along and across the shore are shown in figure 2. The background sediments consist of quartz rich sands. Detailed sedimentary signatures of these reported extreme wave events laterally will provide convincing evidence of the existence of any diagnostic signatures. Our present paper will examine the diagnostic properties of extreme wave events and will add new updates in diagnosing these events.

\section{Regional setting}

The study region lies on the Coromandel Coast, around $55 \mathrm{~km}$ south of southeast coast of India (figure 1). Mahabalipuram shoreline is characteristically NNE-SSW oriented (Vora and Sundaresh 2003). On the southern side, River Palar joins and Buckingham canal occupies the western side. The region is dominated with carbonated sediments, which cover the outer shelf with sand, silt and silty clay (Vaz 1996) and the inner shelf is mostly covered with sandy sediments (Selvaraj and Ram Mohan 2003). In the near shore zone off Mahabalipuram, granitic boulder outcrops with sand patches can be seen. Some archeological evidences show the presence of man-made structures around 1500 years old, 5-8 m below water level, about $800 \mathrm{~m}$ from the present shoreline. Certain evidences for coastal retreat were also found through underwater exploration on the northeastern side of Shore temple. The run up height and inundation limit of the study region is $4.3 \mathrm{~m}$ and $650 \mathrm{~m}$, respectively (Srinivasulu et al 2007).

\section{Methodology}

We analyzed twelve trench samples of respective depths (figure 2; S1a - 1 m; S1b - $1.5 \mathrm{~m} ; \mathrm{S} 1 \mathrm{c}-1 \mathrm{~m}$; $\mathrm{R} 1 \mathrm{a}-1 \mathrm{~m} ; \mathrm{R} 1 \mathrm{~b}-0.5 \mathrm{~m} ; \mathrm{R} 1 \mathrm{c}-0.5 \mathrm{~m} ; \mathrm{R} 2 \mathrm{a}-0.75 \mathrm{~m}$; $\mathrm{R} 2 \mathrm{~b}-0.5 \mathrm{~m} ; \mathrm{R} 2 \mathrm{c}-0.5 \mathrm{~m} ; \mathrm{R} 3 \mathrm{a}-1 \mathrm{~m} ; \mathrm{R} 3 \mathrm{~b}-1 \mathrm{~m}$; R3c $-1.5 \mathrm{~m}$ ) using two sets of proxies: granularity analysis and Scanning Electron Microscope (SEM) studies for identifying extreme wave events. Total station surveys were carried out to obtain the elevation with respect to mean sea level for the study area.

\subsection{Granularity analysis}

The grain-size distribution analysis of high-energy event deposits was determined with a Malvern Mastersizer 2000 particle size analyzer. For the analysis, samples were taken of size $<10 \mu \mathrm{m}$, and were treated with $\mathrm{H}_{2} \mathrm{O}_{2}$ to eradicate clay particles and dried in an oven. The measurement process consists of creating a measurement file, measuring the background readings of the dispersant, adding samples to the system and taking at least three sets of readings and flushing of the stirring and pumping mechanism and the flow cell before reading the background for the next sample.

\subsubsection{Sieve analysis}

Sieve analysis method was carried out to determine the grain-size parameters like mean size, standard deviation, skewness, and kurtosis. Initially, the sediments were weighed and allowed to pass through sieves of various mesh sizes $(0.75 \mathrm{~mm}$ to $2.36 \mathrm{~mm}$ ), with the aid of sieve shaker.

\subsection{SEM studies}

JSM JEOL 6490 Scanning Electron Microscope $(\mathrm{SEM})$ with a high resolution of $3.0 \mathrm{~nm}$ performed 


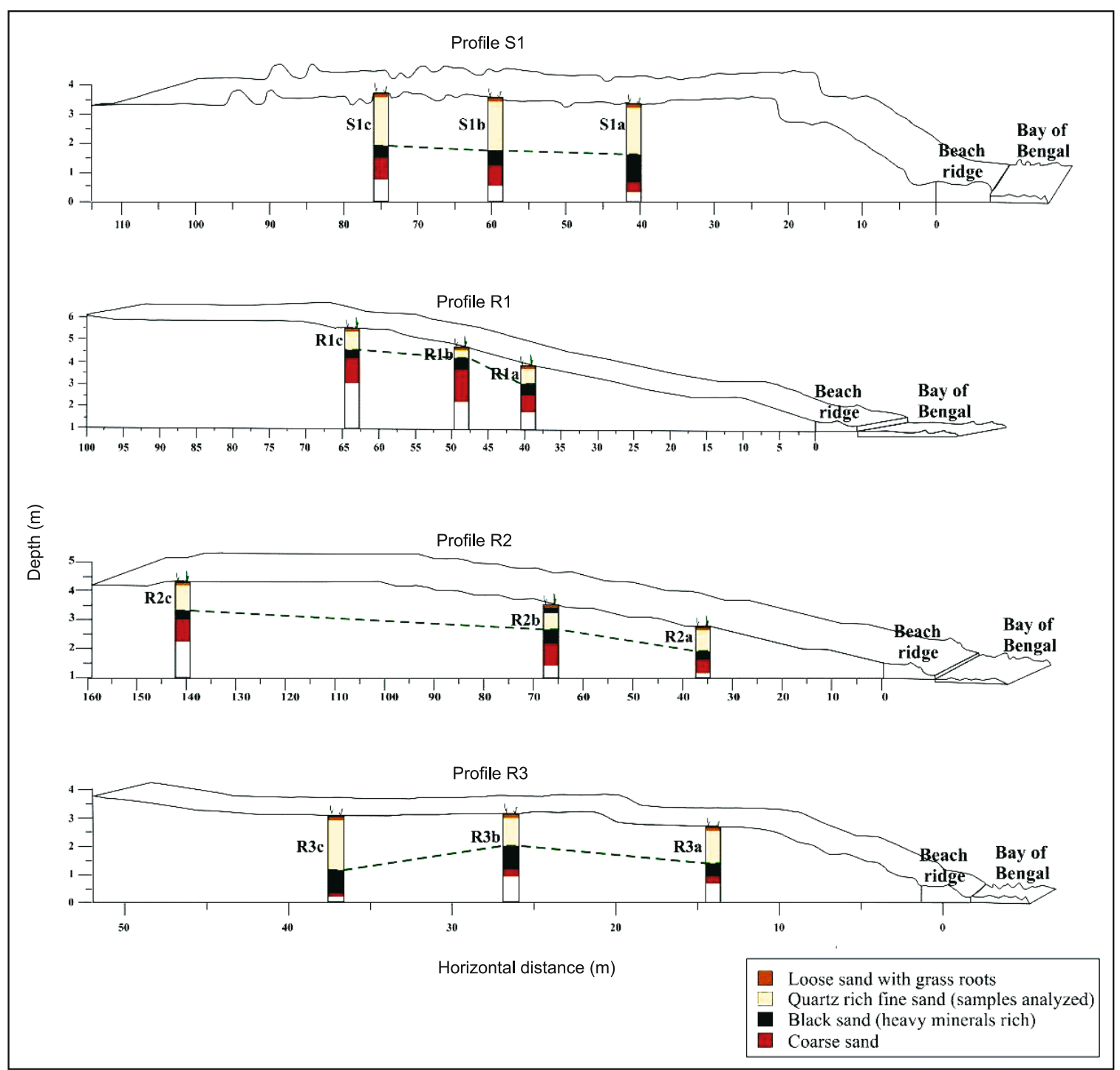

Figure 2. Vertical sections is plotted with elevation (with respect to mean sea level) of twelve trenches S1a, S1b, S1c, R1a, R1b, R1c, R2a, R2b, R2c, R3a, R3b, and R3c from profiles S1, R1, R2 and R3, respectively, from where samples were collected showing lateral continuation.

a microscopic analysis of grains. The tracer energy dispersive X-ray detector (EDS) provides a qualitative analysis of major elements with their atomic numbers. The sample should have a conductive carbon coating applied to the surface and should be free from volatiles. Typical samples are small enough to be mounted on $\mathrm{Al}$ cylinder of diameter $1 \mathrm{~cm}$. The heavy minerals were analyzed by treating the samples with bromoform to eliminate impurities, dried and then the slides were prepared.

\section{Results}

Sedimentological analysis revealed the landward and upward fining deposits of the analyzed sediments. The grain-size distribution analysis (figure 3) of these extreme wave event deposits along the transects shows a landward fining trend as the mode shifts to higher phi values (up to 13 phi units), with increasing distance from the shore for majority of the sand particles and a very small fraction of silt $(1 \%)$. The results of sieve analysis are summarized in table 1 . The grain size varies from fine-to-medium with the phi mean value ranging from 1.35 to 1.95 and the standard deviation ranging from 0.45 to 0.78 , exhibiting moderately well to well-sorted sediments. The grains exhibit positive skewness with platykurtic to leptokurtic nature. Figure 4 describes the frequency weight percentage graph of sand particles showing bimodal distribution curve of sands and figure 5 shows the cumulative weight percentage curve exhibiting a uniform distribution curve of the sand particles. The angular character exhibited by quartz and feldspar grains can be perceived by 


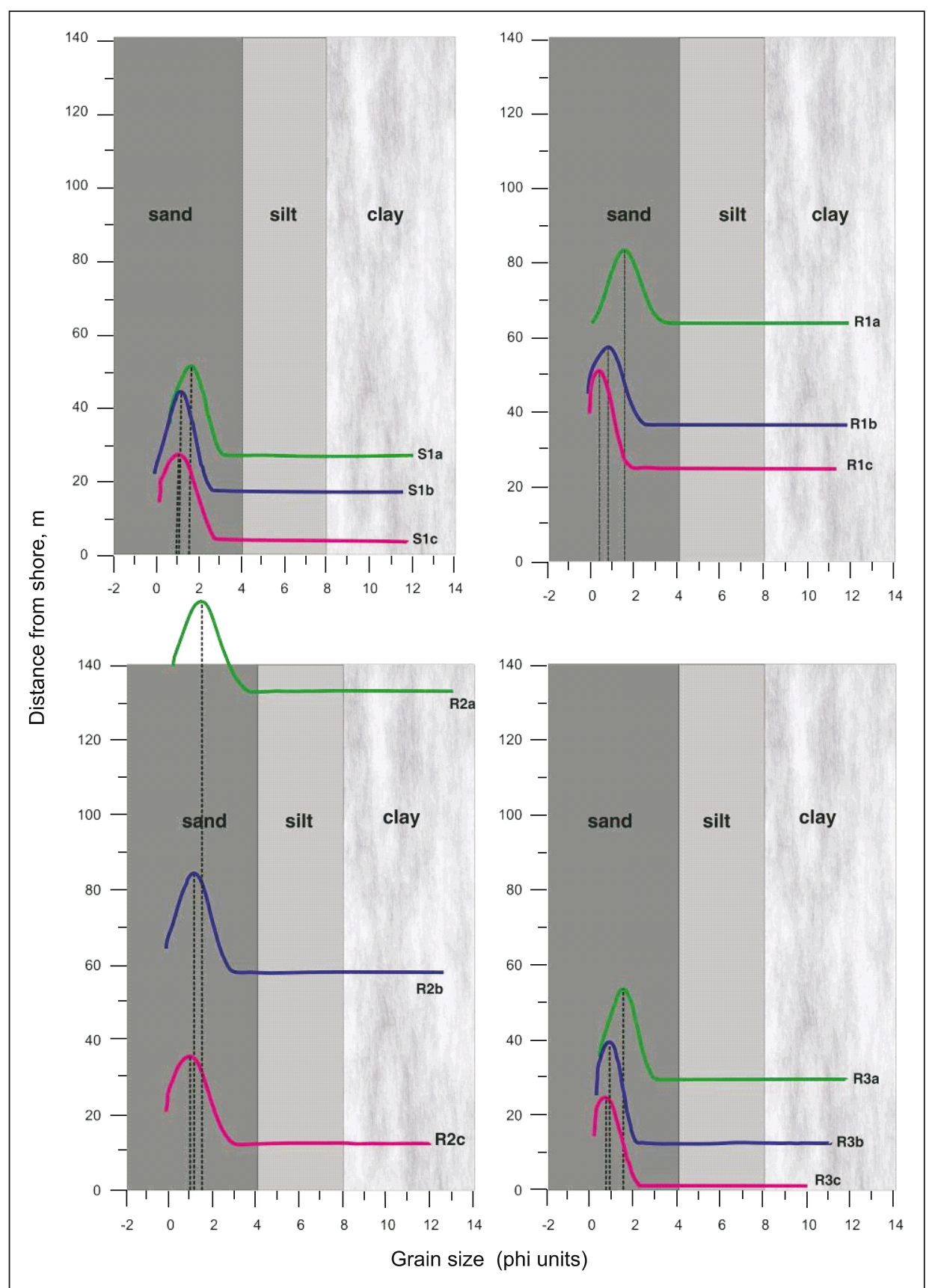

Figure 3. Grain-size distribution curves of the sand particles analyzed from the trench profile S1 (S1a, S1b, S1c), R1 (R1a, R1b, R1c), R2 (R2a, R2b, R2c), and R3 (R3a, R3b, R3c) (see figure 1 for location). The profile shows a fining landward sequence.

the SEM studies (figure 6). Heavy minerals such as monazite, magnetite, ilmenite, garnet, zircon, etc., along with quartz, feldspar, olivine and sphene were observed as homogeneous deposits. SEM portrays the development of micro-features on the ilmenite grain as shown in figure 7 , with crescent and pit structures on surfaces. Thin dark laminae rich in heavy minerals with a good proportion of magnetite mark the basal contacts of the quartz rich fine sand layers analyzed.

\section{Discussions}

Grain-distribution analysis along shore normal transects shows landward thinning sequences, as the mode shifts to higher phi values with increasing distance from the shore (Monecke et al 2008). From the graphical logs, we obtained the upward fining sequences as the coarse sand occupies the bottom layer overlain by heavy mineral layer and quartz rich fine sand layer. Goff et al (2001) demonstrated 
Table 1. Results of grain-size parameters (mean value, standard deviation, skewness and kurtosis value) of all the samples from profile S1, R1, R2, and R3. $M S$ - medium sand, FS-fine sand, MWS - moderately well sorted, WS - well sorted, FSK - finely skewed, LK - leptokurtic, PK - platykurtic.

\begin{tabular}{llcccl}
\hline Profile & Mean & $\begin{array}{c}\text { Standard } \\
\text { deviation }\end{array}$ & Skewness & Kurtosis & \multicolumn{1}{c}{ Remarks } \\
\hline S1a & 1.73 & 0.6 & 0.18 & 1.45 & MS, MWS, FSK, LK \\
S1b & 1.65 & 0.78 & 0.68 & 1.15 & MS, MWS, FSK, LK \\
S1c & 1.95 & 0.5 & 0.08 & 0.79 & FS, WS, FSK, PK \\
R1a & 1.87 & 0.48 & 0.15 & 0.83 & FS, WS, FSK, PK \\
R1b & 1.35 & 0.67 & 0.122 & 1.64 & MS, MWS, FSK, LK \\
R1c & 1.6 & 0.45 & 0.27 & 3.88 & MS, WS, FSK, LK \\
R2a & 1.78 & 0.46 & 0.28 & 0.87 & MS, WS, FSK, PK \\
R2b & 1.9 & 0.51 & 0.245 & 0.87 & FS, WS, FSK, PK \\
R2c & 1.73 & 0.63 & 0.14 & 1.71 & MS, MWS, FSK, LK \\
R3a & 1.74 & 0.54 & 0.276 & 1.35 & MS, WS, FSK, LK \\
R3b & 1.67 & 0.51 & 0.126 & 1.38 & MS, WS, FSK, LK \\
R3c & 1.71 & 0.54 & 0.166 & 2.14 & MS, WS, FSK, LK \\
\hline
\end{tabular}

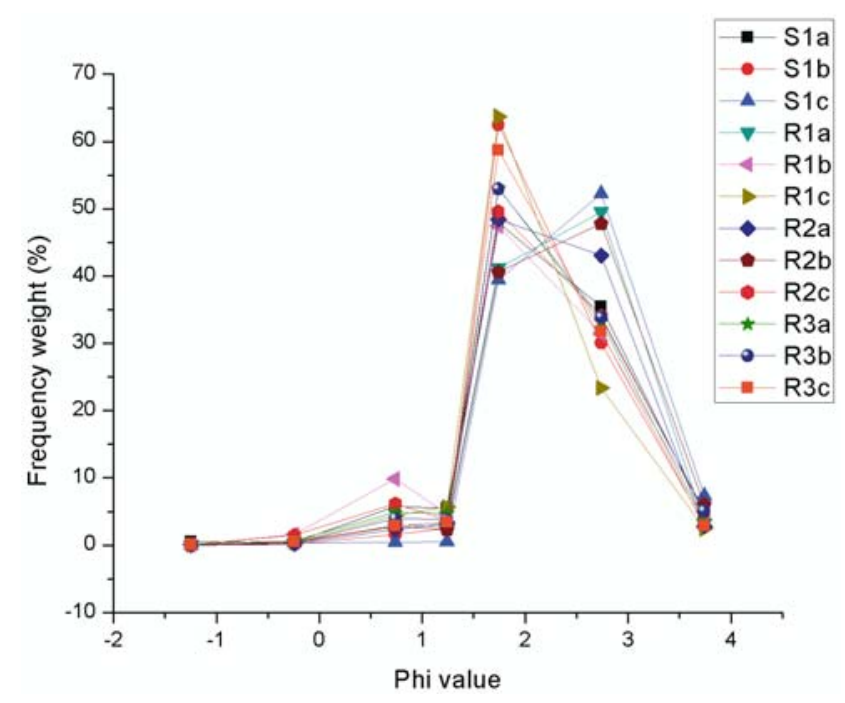

Figure 4. Frequency weight percentage curve showing bimodal distribution of beach sediments.

that landward fining as well as upward fining sequence is a general trait of tsunami deposits, e.g., 1992 tsunami in Flores (Shi et al 1995; Minoura et al 1997). The presence of mediumsized sand indicates that the deposition might have been formed under a high-energy condition and fine sands correspond to moderately lowenergy conditions. The moderately well sorted to well sorted sediments obtained might be due to the sudden winnowing action or back and forth motion of the sediments by the depositing agent (Singarasubramanian et al 2009). Such action of the depositing agent might be responsible for the positive skewness of the sediments (0.08-0.68), and also the unidirectional transport or deposition of sediments in low energy

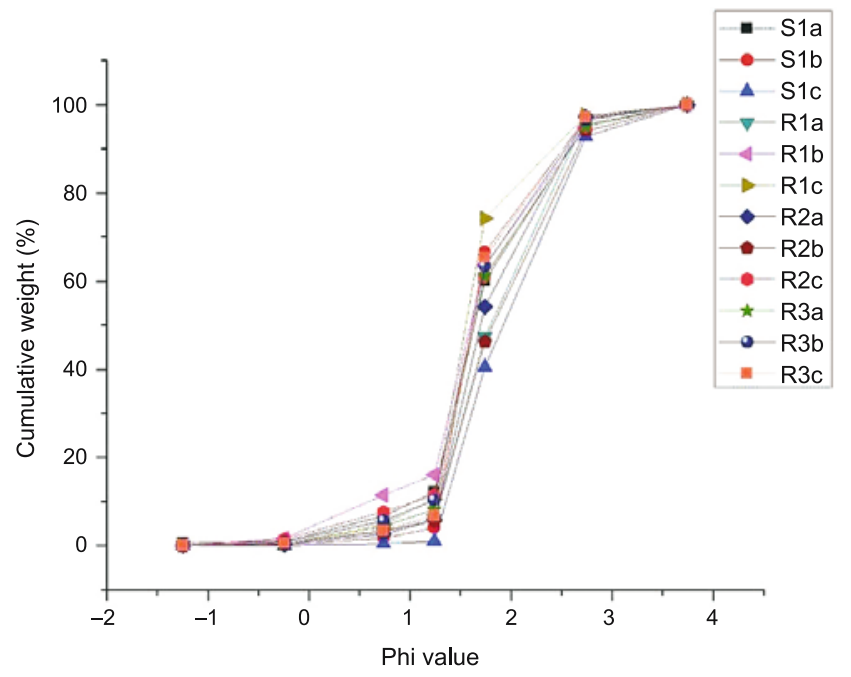

Figure 5. Cumulative weight percentage curve of the beach sediments.

environment in agreement with the observation made by Brambati (1969), (table 1; Friedman 1961). The well sorting might be due to the intermixing of the sediments from the sea as well as the river and that the fine skewness indicates excessive riverine input (Singarasubramanian et al 2006). Our study region is devoid of sedimentary structures that permit the derivation of current directions. Platykurtic nature of the grains indicate high-energy environment and the leptokurtic character reveals the energy fluctuations of the depositing medium (Singarasubramanian et al 2009). As suggested by Friedman (1962), we obtained moderately well sorted sediments in high-energy environment, which could be inferred by the extremely high or low values of kurtosis (platykurtic to leptokurtic). The frequency weight 


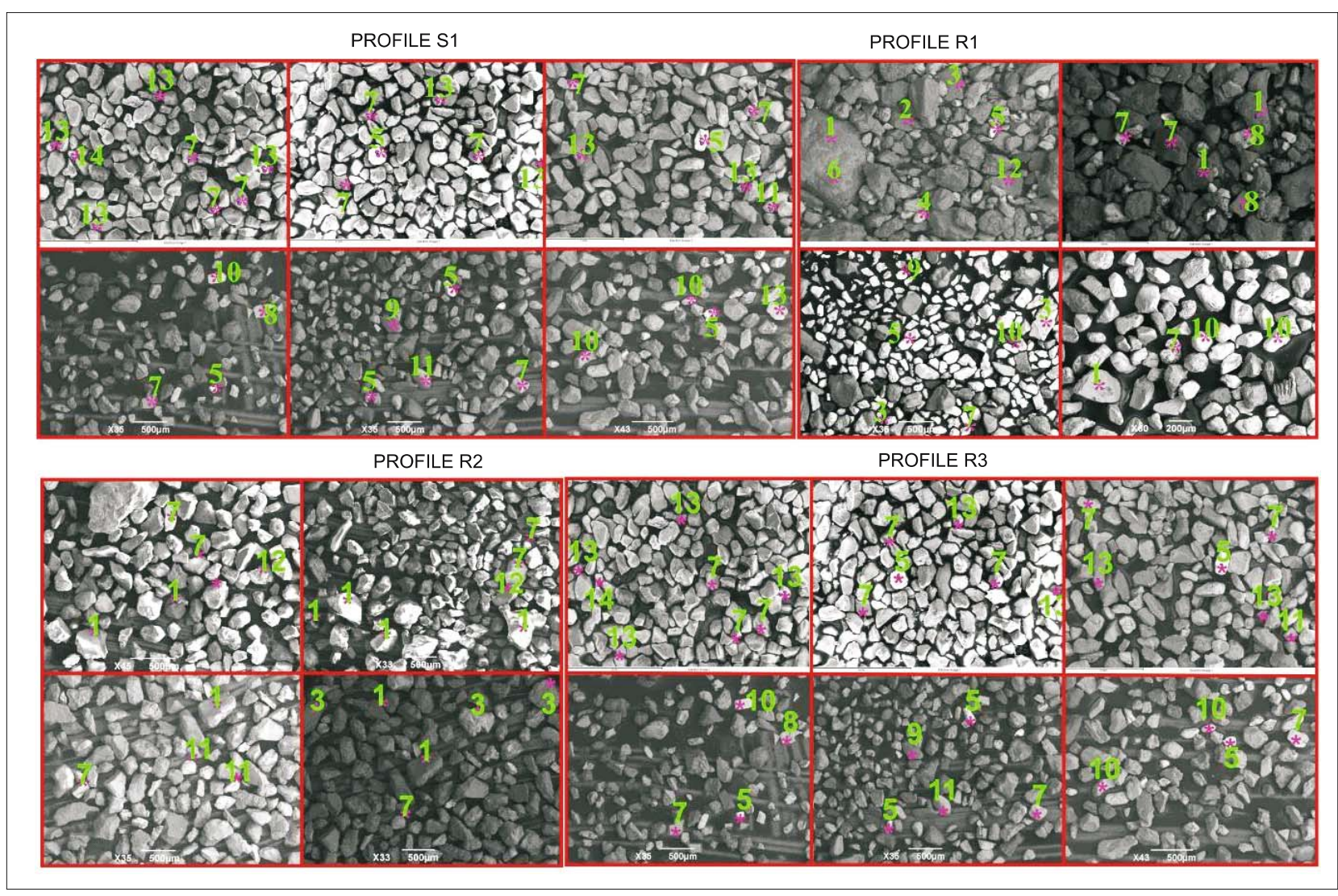

Figure 6. SEM microphotographs of the minerals that underwent high deformational episode with mineral names. 1. Quartz, 2. Calcic plagioclase, 3. K Feldspar, 4. Olivine, 5. Monazite, 6. Pyroxene, 7. Ilmenite, 8. Sphene, 9. Garnet, 10. Zircon, 11. Rutile, 12. Plagioclase feldspar, 13. Magnetite, and 14. Amphibole.

percentage curve (figure 4) results in a bimodal distribution curve, suggesting that the source of deposition is of multiple origin, and the cumulative weight percentage curve (figure 5) advocated the existence of fine sand which provide an idea about uniform suspension mechanism of transport during extreme wave event. We now deduce that grain sizes always have a great control over the transportation of extreme wave event deposits and are controlled by the source of sediment as well as the topography of the region (Dawson et al 1996; Gelfenbaum and Jaffe 2003; Jaffe et al 2003; Nanayama and Shigeno 2006). The grain size of deposits depends upon the grain size of the sediment available for transportation (Srinivasulu et al 2007).

From figure 6, we observed the angular character of the quartz grains from SEM studies, which might be due to the transportation of sediments from offshore to land which is not subjected to the beach rounding of sand grains (Dahanayake and Kulasena 2008). The sediments were devoid of marine fossils indicating that sands were originated from a seaward source that were transported by flooding events associated with extreme wave events as exhibited in the southern Kuril trench reported by Nanayama et al (2007) and substantiated the considerable alteration patterns on the placer minerals. Intense alteration observed on the grains might be due to the mixing of shelf sediments with the onshore sands. Buynevich et al (2007) reported that the HMCs could be used as proxies for sediment transport and as sedimentological marker horizons. As analogous to the findings of Babu et al (2007) in southwest coast of India, we obtained good proportion of magnetite $($ density $=5.2)$, which can be contributed due to extreme wave events, as normal waves and storms are incapable of transporting such high density minerals. SEM portrays the development of micro features on the ilmenite grain as shown in figure 7 . Surface texture of the grains provides a better understanding of the depositional history of the sediments. Figure 7(a) reveals the high intensity of wave action that caused severe deformation of ilmenite mineral obtained from trench $\mathrm{R} 1$ sediments. From figure 7(b), the observed crescent and pit structure in the ilmenite mineral (trench R2) is suggestive of the solution activity (Krinsley and Doornkamp 1973). Micromorphological changes as well as the abundance of heavy minerals including magnetite perceived by SEM studies could be 
(a)

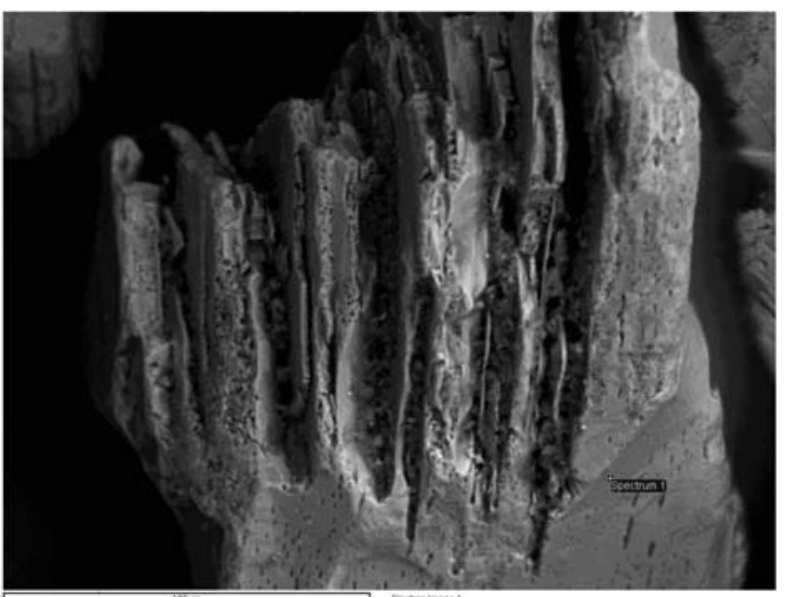

(b)

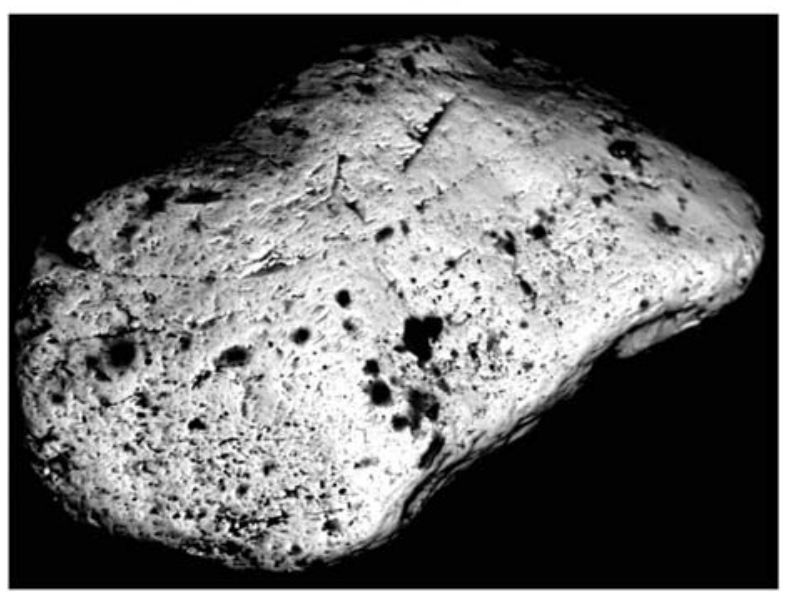

Figure 7. SEM microphotograph of altered ilmenite of tsunami sediments (a) samples of trench R1 and (b) trench sample R2.

due to the transportation of deeper sediments of onshore region during the extreme wave events similar to those obtained by Babu et al (2007). Textural analyses as well as the grain-size analysis of sediments thus enable us to understand the energy conditions and energy fluctuations of the depositional environment (Visher 1969; Sly et al 1983).

\section{Conclusions}

Our results convey that the samples analyzed underwent the episode of a high-energy event. From detailed sedimentological studies, we obtained landward thinning deposits indicating the repeated wave attack with different wave velocities that brought significant sediments from offshore to land. Presence of fine-to-medium sand, moderately well to well-sorted sediments indicating sudden winnowing action by the depositing agent, positive skewness signifying the unidirectional transport as well as deposition, and platy to leptokurtic nature indicating energy fluctuations of depositing medium sheds light on extreme wave events as one possibility of tsunami. The presence of magnetite content in a good proportion provides a strong evidence that the analyzed sediment were of extreme high-energy wave event origin as the normal waves and storms are incapable of transporting such a high-density mineral. The altered ilmenite along with the above results provides a powerful validation that the sediments underwent a high deformational history and add a new update for diagnostic features. Our present integrated methodology using proxies such as granularity and textural analysis provide opportunity to identify and map the extreme wave events. Further detailed studies will help to settle the issue of distinguishing among these extreme wave events.

\section{Acknowledgements}

INCOIS 283/2007/2909 and DST SR/S4/ES-317/ 2008 , India funded this work. We thank Dr Ilya V Buynevich for his valuable suggestions. Archeological Survey of India, Chennai, is acknowledged for their kind permission to carry out the field work. We sincerely thank the reviewer for the insightful suggestions that helped in improving the manuscript.

\section{References}

Babu N, Suresh Babu D S and Mohan Das P N 2007 Impact of tsunami on texture and mineralogy of a major placer deposit in southwest coast of India; Environ. Geol. 52 71-80.

Bahlburg H and Weiss R 2007 Sedimentology of the December 26, 2004, Sumatra tsunami deposits in eastern India (Tamil Nadu) and Kenya; Int. J. Earth Sci. (Geol. Rundsch) 96 1195-1209.

Brambati A 1969 Stratigraphy and sedimentation of Siwaliks of northeastern India; Proc. Inter. Sem, Intermontane Basins: Geology and Resources, Chiang Mai, Thailand, 427-439.

Buynevich I V, Fitz Gerald D M and Goble R J 2007 A 1500 yr record of North Atlantic storm activity based on optically dated relict beach scarps; Geology $\mathbf{3 5}$ 543-546.

Costa P 2006 Geological recognition of abrupt marine invasions in two coastal areas of Portugal, MPhil Thesis, Brunel University.

Dawson A G 1996 The geological significance of tsunamis; Z. Geomorphol. Supplementband. 102 199-210.

Dawson A G 1999 Linking tsunami deposits, submarine landslides and offshore earthquakes; Quat. Int. 60 $119-126$.

Dawson A G, Shi S, Dawson S, Takahashi T and Shuto N 1996 Coastal sedimentation associated with the June 2nd and 3rd, 1994 Tsunami in Rajegwesi, Java; Quat. Sci. Rev. 15 901-912.

Dahanayake K and Kulasena N 2008 Recognition of diagnostic criteria for recent- and paleo-tsunami sediments from Sri Lanka; Mar. Geol. 254 180-186. 
Friedman G M 1961 Distinction between (sic) dune, beach and river sands from their textural characteristics; J. Sedim. Petrol. 31 514-529.

Friedman G M 1962 On sorting, sorting coefficients and the $\log$ normality of the grain-size distributions of sandstones; J. Geol. 70 737-753.

Gelfenbaum G and Jaffe B 2003 Erosion and sedimentation from the 17 July, 1998 Papua New Guinea tsunami; Pure Appl. Geophys. 160 1969-1999.

Goff J R, Chagué-Goff C and Nichol S L 2001 Paleotsunami deposits: A New Zealand perspective; Sedim. Geol. 143 $1-6$.

Goff J R, McFadgen B G and Chagué-Goff C 2004 Differences between storm and 15th century tsunami deposits; Mar. Geol. 204 235-250.

Jaffe B E, Gelfenbaum G, Rubin D, Peters R, Anima R, Swensson M, Olcese D, Bernales L, Gomez J and Riega P 2003 Identification and interpretation of tsunami deposits from the June 23, 2001 Peru tsunami; Proceedings of the International Conference on Coastal Sediments 2003 , World Scientific Publishing Corp., and East Meets West Productions, Corpus Christi, TX, USA, p 13.

Jaffe B E, Morton R, Gelfenbaum G and Richmond B M 2006 Differentiating between tsunami and storm deposits; In: First international tsunami field symposium, abstracts, vol. 17

Jankaew K, Atwater B F, Sawai Y, Choowong M, Charoentitirat T, Martin M E and Prendergast A 2008 Medieval forewarning of the 2004 Indian ocean tsunami in Thailand; Nature 455 1228-1231.

Kortekaas S and Dawson A G 2007 Distinguishing tsunami and storm deposits: An example from Martinhal, SW Portugal; Sedim. Geol. 200 208-221.

Krinsley D H and Doornkamp J C 1973 Atlas of quartz sand surface textures, Cambridge University Press, Cambridge, p. 37.

Minoura K, Imamura F, Takahashi T and Shuto N 1997 Sequence of sedimentation processes caused by the 1992 Flores tsunami: Evidence from Babi Island; Geology 25 $523-526$.

Monecke K, Finger W, Klarer D, Kongko W, McDoo B G, Moore A L and Sudrajat S U 2008 A 1000-year sediment record of tsunami recurrence in northern Sumatra; Nature $4551232-1234$.

Morton R A, Gelfenbaum G and Jaffe B E 2007 Physical criteria for distinguishing sandy tsunami and storm deposits using modern examples; Sedim. Geol. 200 184-207.

Nanayama F, Shigeno K, Satake K, Shimokawa K, Koitabashi S, Miyasaka S and Ishii M 2000 Sedimentary differences between the 1993 Hokkaido-nansei-oki tsunami and the 1959 Miyakojima typhoon at Taisei, southwestern Hokkaido, northern Japan; Sedim. Geol. 135 255-264.
Nanayama F and Shigeno K 2006 Inflow and outflow facies from the 1993 tsunami in southwest Hokkaido, northern Japan; Sedim. Geol. 187 139-158.

Nanayama F, Furukawa R, Shigeno K, Makino A, Soeda Y and Igarashi Y 2007 Nine unusually large tsunami deposits from the past 4000 years at Kiritappu marsh along the southern Kuril Trench; Sedim. Geol. 200 $275-294$

Paris R, Lavinge F, Wasmmer P and Sartohadi J 2007 Coastal sedimentation associated with the December 26, 2004 tsunami in Lhok Nga, west Banda Aceh (Sumatra, Indonesia); Mar. Geol. 238 93-106.

Rajendran C P, Rajendran K, Machado T, Satyamurthy T, Aravazhi P and Jaiswal M 2006 Evidence of ancient sea surges at the Mamallapuram coast of India and implications for previous Indian Ocean tsunami events; Curr. Sci. 91(9) 1242-1247.

Selvaraj K and Ram Mohan V J 2003 Textural variation and depositional environments of innershelf sediments, off Kalpakkam, southeast coast of India; J. Geol. Soc. India 61 449-462.

Shi S, Dawson A G and Smith D E 1995 Coastal sedimentation associated with the December 12th, 1992 tsunami in Flores, Indonesia; Pure Appl. Geophys. 144 525-536.

Singarasubramanian S R, Mukesh M V, Manoharan K, Murugan S, Bakkiaraj D, John Peter A and Seralathan P 2006 Sediment characteristics of the M-9 tsunami event between Rameswaram and Thoothukudi, Gulf of Mannar, southeast coast of India; Sci. Tsunami Haz. 25 $160-172$.

Singarasubramanian S R, Mukesh M V, Manoharan K, Seralathan P, Sujatha K and Bakkiaraj D 2009 Geomorphological and sedimentological changes during and after the December 2004 Indian Ocean tsunami near the Vellar river and the M.G.R. Island area of the central Tamil Nadu coast, India; Sci. Tsunami Haz. 28 67-74.

Sly P G, Thomas R L and Pelletier B R 1983 Interpretation of moment measures derived from waterlain sediments; Sedimentology 30 219-233.

Srinivasulu S, Thangadurai N, Switzer A D, Ram Mohan V and Ayyamperumal T 2007 Erosion and sedimentation in Kalpakkam (N Tamil Nadu, India) from the 26th December 2004 tsunami; Mar. Geol. 240 65-75.

Tappin D R 2007 Sedimentary features of tsunami deposits their origin, recognition and discrimination: An introduction; Sedim. Geol. 200 151-154.

Vaz G G 1996 Relict coral reef and evidence of Pre-Holocene sea level standoff Mahabalipuram, Bay of Bengal; Curr. Sci. 71(3) 240-242.

Visher G S 1969 Grain size distribution and depositional process; J. Sedim. Petrol. 39 1074-1106.

Vora K H and Sundaresh 2003 Mahabalipuram: A saga of glory to tribulations; Migration $\&$ Diffusion 4 67-80. 